\title{
ANALISIS AFIKSASI PADA TEKS EKSPOSISI KARANGAN SISWA KELAS 8 SMP BINA MANDIRI TELUKNAGA (KAJIAN MORFOLOGI)
}

\author{
Maulana Yusuf ${ }^{\mathbf{1}}$ \\ Universitas Muhammadiyah Tangerang \\ my.maul24@gmail.com, \\ Ira Anisa Purawinangun² \\ Universitas Muhammadiyah Tangerang \\ irapurawinangun@gmail.com \\ Nori Anggraini ${ }^{3}$ \\ Universitas Muhammadiyah Tangerang \\ nory_agg@yahoo.com
}

\begin{abstract}
ABSTRAK
Penelitian ini bertujuan untuk mendeskripsikan afiksasi yang terkandung dalam teks eksposisi karangan siswa kelas 8 SMP Bina Mandiri Teluknaga. Jenis penelitian dalam penelitian ini yaitu menggunakan penelitian kualitatif. Metode yang digunakan yaitu metode analisis. Data dalam penelitian ini yakni teks eksposisi karangan siswa kelas 8 SMP Bina Mandiri Teluknaga, dalam penelitian ini sumber data dibagi atas dua jenis yakni data primer dan data sekunder, data primer yakni teks eksposisi karangan siswa kelas 8 SMP Bina Mandiri Teluknaga dan data sekunder yakni buku, jurnal ilmiah, dan data terkait dengan penelitian ini. Teknik pengumpulan data dalam penelitian ini dengan mengumpulkan data dari sekolah dan menganalisis data. Berdasarkan hasil penelitian ini dapat disimpulkan ditemukan afiksasi yang terkandung di dalam teks ekpsosisi karangan siswa kelas 8 SMP Bina Mandiri Teluknaga antara lain: a) prefiks; meN-/meng-, ber-, ter, b) sufiks; -an dan -kan, dan c) konfiks; ke - an dan pe-an, sedangkan infiks tidak ditemukan dalam penelitian ini. Bentuk kata yang telah mendapatkan afiksasi pada teks ekspsosisi karangan siswa tersebut membentuk makna meliputi verba dan nomina.
\end{abstract}

Kata kunci: afiksasi, morfologi, teks eksposisi

\section{A. PENDAHULUAN}

Afiksasi sebagai cabang ilmu morfologi memiliki peranan sebagai pembubuhan imbuhan pada bentuk kata dasar guna memiliki makna turunan yang baru. Pembelajaran afiksasi dapat dijumpai di dalalm mata pelajaran bahasa Indonesia sebagai salah satu muatan mata pelajaran nasional, pembelajaran afiksasi tidak secara jelas atau dikhususkan. Namun diimplementasikan ke dalam materi pembelalajaran yang berbasis teks pada mata pelajaran bahasa Indonesia. Pada pelaksanaannya, pembelajaran berbasis teks bahasa Indonesia terbagi atas dua jenis kategori teks yakni teks fiksi dan teks nonfiksi. Teks eksposisi dalam lingkup pembelajaran berbasis teks tergolong ke dalam jenis teks nonfiksi. Teks nonfiksi dapat 


\section{Lingua Rima: Jurnal Pendidikan Bahasa dan Sastra Indonesia \\ Vol. 11 No. 1 Januari 2022 \\ http://jurnal.umt.ac.id/index.php/lgrm}

dimaknai sebagai bentuk teks yang disusun secara berdasarkan fakta, dengan kata lain tidak berdasarkan imajiner pengarang.

Morfologi secara garis besar dapat dipahami sebagai ilmu yang mempelajari seluk beluk pembentukan kata atau struktur kata. Chaer (2015) mengungkapkan bahwa morfologi merupakan studi mengenai bentuk dan pembentukan kata. Pembentukan kata dapat didefinisikan sebagai proses sebuah kata mendapatkan maknanya melalui proses morfologi. Ramlan (2001) menemukakan bahwa morfologi merupakan bagian ilmu bahasa yang mengkaji seluk beluk kata serta pengaruh perubahan-perubahan bentuk kata terhadap golongan dan arti kata. Lebih lanjut, Pohan (2019) mengungkapkan bahwa morfologi merupakan salah satu bidang kajian linguistik yang mengkaji tentang struktur kata. Proses pembentukan kata dan arti kata tersebut terjadi akibat dari adanya proses morfologi pada suatu kata.

Pada morfologi, terdapat bentuk-bentuk linguistik yang dipelajari di dalamnya yakni morf, alomorf, morfem, dan kata. Morf dapat dipahami sebagai bentuk kata yang belum diketahui statutsnya, Azwardi (2015) mengungkapkan bahwa morf merupakan penamaan dari bentuk yang belum diketahui statusnya. Senada dengan pendapat di atas, Verhaar (2012) mengemukakan bahwa morf merupakan penguraian dari unsur-unsur yang cukup konkret, sedangkan Busri dan Badrih (2018) memandang bahwa morf mrtupakan bentuk satuan paling kecil dan telah memiliki arti. Berdasarkan pendapat di atas, dapat disimpulkan bahwa morf merupakan bentuk konkret satuan terkecil yang memiliki arti, namun belum diketahui statusnya.

Alomorf dapat dipahami sebagai ilmu morfologi yang mempelajari bentuk kata yang telah diketahui statusnya, Munandar (2016) mengemukakan bahwa alomorf merupakan anggota dari morfem yang posisinya telah ditentukan dan berfungsi sebagai komplementer. Lebih lanjut, Bunau (2017) menyebut bahwa alomorf masing-masing telah berketentuan. Berdasarkan hal tersebut, dapat disimpulkan bahwa alomorf merupakan bagian dari morfem yang telah diketahui statusnya dan berketentuan.

Morfem merupakan bentuk bahasa terkecil dan memiliki makna yang relatif tetap dan tidak dapat dibagi kembali menjadi makna yang lebih kecil. Hal tersebut dikemukakan Rumilah dan Cahyani (2020) dan Mandia (2019) yang memandang bahwa morfem merupakan satuan unsur gramatik tekecil yang tidak dapat dibagi atau dipecah kembali menjadi bagian yang lebih kecil. Morfem sebagai unsur satuan terkecil memiliki makna dan 


\section{Lingua Rima: Jurnal Pendidikan Bahasa dan Sastra Indonesia \\ Vol. 11 No. 1 Januari 2022 \\ http://jurnal.umt.ac.id/index.php/lgrm}

tidak dapat dibagi menjadi bagian yang lebih kecil. Sedangkan kata dapat didefinisikan sebagai bentuk satuan bebas yang telah memiliki makna/arti, hal ini dikemukakan Nuryadi (2019) yang memandang bahwa kata merupakan satuan bebas yang diujarkan, dapat berdiri sendiri, dam dapat dipisahkan dari bentuk bebas lainnya. Lebih lanjut Masita dan Duwila (2019) menggagas bahwa kata merupakan bentuk satuan terbesar di dalam ilmu morfologi. Hal tersebut membuat kata dapat dipahami sebagai unsur satuan terbesar yang memiliki makna.

Afiksasi dapat dipahami sebagai cabang ilmu dari morfologi yang mempelajari tentang pengimbuhan pada bentuk kata dasar. Kridalaksana (2009) mengemukakan bahwa afiksasi merupakan perubahan leksem menjadi kata yang kompleks. Lebih lanjut Mulyono (2013) berpendapat bahwa afiksasi merupakan proses pembentukan kata dengan cara membubuhkan afiks terhadap bentuk kata dasar baik berupa pokok kata, asal kata, maupun bentuk kata lainnya. Berdasarkan pendapat di atas, dapat ditarik simpulan bahwa afiksasi merupakan proses pembubuhan imbuhan yang dapat dilakukan pada bentuk kata dasar guna membentuk kata yang lebih kompleks. Umumnya jenis afiks yang ditemukan adalah prefiks, infiks, sufiks, dan konfiks.

Prefiks dapat dipahami sebagai pembubuhan imbuhan pada awal bentuk kata dasar. Herawati (2019) mengemukakan bahwa prefiks merupakan afiks yang dituliskan di kiri bentuk kata dasar. Senada dengan pendapat di atas, Jannah (2020) mengemukakan bahwa prefiksasi merupakan proses pengimbuhan bunyi pada awal sebuah kata yang menghasilkan kata baru dan kemudian tetap berhubungan dengan asal kata. Berdasarkan hal tersebut dapat disimpulkan bahwa prefiks merupakan pembubuhan imbuhan pada awal kata dasar sehingga membentuk kata baru yang tetap berkaitan dengan kata dasar sebelumnya.

Infiks dapat didefinisikan sebagai bentuk imbuhan pada tengah kata dasar. Mardiyah, dkk (2019) mengemukakan bahwa infiks merupakan imbuhan yang diletakkan pada lajur tengah dari bentuk kata dasar. Lebih lanjut, Kencanawati, dkk (2017) menyebut bahwa di dalam bahasa Indonesia terdapat varian infiks -el-, -em-, -er-, dan -in-, namun penggunaannya tidak lagi produktif. Berdasarkan pendapat di atas, dapat disimpulkan bahwa infiks merupakan salah satu jenis afiksasi yang membubuhkan imbuhannya pada tengah dari bentuk kata dasar.

Sufiks dapat dipahami sebagai bentuk imbuhan pada akhir dari bentuk kata dasar. Nurfauziah dan Latifah (2019) mengungkap bahwa sufiks merupakan sebuah proses pemberian imbuhan dengan menempatkannya setelah bentuk kata dasar, sedangkan konfiks 


\section{Lingua Rima: Jurnal Pendidikan Bahasa dan Sastra Indonesia \\ Vol. 11 No. 1 Januari 2022 \\ http://jurnal.umt.ac.id/index.php/lgrm}

merupakan bentuk imbuhan yang ditempatkan pada awal dan akhir dari bentuk kata dasar, Kusmiarti dan Fitriayani (2019) mengemukakan bahwa konfiksasi merupakan sebuah proses membubuhi imbuhan pada awal dan akhir kata d asar, sehingga membentuk sebuah kata turunan yang lebih luas atau kompleks. Berdasarkan pendapat di atas, dapat dipahami bahwa sufiks merupakan pemberian imbuhan di akhir kata dasar dan konfiks merupakan pembubuhan imbuhan pada awal dan akhir dari bentuk kata dasar.

Teks eksposisi diajarkan pula di kelas 8 SMP, tepatnya pada KD. 3.6 - 4.6. Berdasarkan kompetensi dasar tersebut, siswa dibimbing untuk dapat memahami mulai dari struktur teks eksposisi hingga dapat menelaaah teks eksposisi. Setelah mengikuti proses kegiatan pembelajaran tersebut, diharapkan siswa mampu memahami dan menerapkan materi pembelajaran yang telah disampaikan dan berdampak kepada keberhasilan dalam proses pembelajaran. Penugasan karangan teks eksposisi kepada siswa diupayakan sebagai bentuk untuk melatih kognitif siswa dalam menyusun teks yang berisi mengenai informasi secara jelas berdasarkan fakta-fakta yang didapatkan.

Pada pelaksanaannya, afiksasi di dalam teks eksposisi pun menghadapi kendala di dalam penyampaiannya, masih dijumpai kesalahan maupun kekeliruan dalam penulisannya. Kesalahan dan kekeliruan tersebut disebabkan karena masih terdapat "kebimbangan" siswa dalam menentukan jenis afiksasi atau jenis preposisi. Kendala-kendala tersebut dapat diminimalisasi dengan cara sering berlatih mengenai penulisan bentuk kata yang mendapat afiksasi yang disesuaikan dengan materi pembelajaran bahasa Indonesia yang berbasis teks, baik teks fiksi maupun teks nonfiksi melalui berbagai media pembelajaran. Pembelajaran dan penugasan tersebut dimaksudkan sebagai bentuk hasil pelatihan kognitif peserta didik yang terkait erat dengan keterampilan berbahasa Indonesia dan sistem 4C.

Karangan merupakan sebuah bentuk aktivitas kreatif dalam menuangkan ide dan ke dalam sebuah media tulis. Finoza (2010) mendefinisikan karangan sebagai aktivitas menjabarkan sebuah ide atau topik secara resmi dan sistematis. Karangan pula dapat dikaitkan dengan keterampilan menulis sebagai bentuk dari keterampilan berbahasa, Sihabuddin (2019) mengemukakan bahwa menulis merupakan bentuk aktivitas yang membutuhkan kreativitas tinggi baik dari segi cara, isi, pemilihan diksi, dan gaya bahasa guna mengesankan pembaca. Berdasarkan pendapat di atas dapat disimpulkan bahwa karangan merupakan wujud implementasi keterampilan menulis sebagai bentuk aktivitas kreatif yang dituangkan ke dalam media tulis. 


\section{Lingua Rima: Jurnal Pendidikan Bahasa dan Sastra Indonesia \\ Vol. 11 No. 1 Januari 2022 \\ http://jurnal.umt.ac.id/index.php//grm}

Materi pembelajaran mata pelajaran bahasa Indonesia pada tingkat SMP dibagi atas dua kategori yakni teks fiksi dan teks nonfiksi, salah satu jenis teks nonfiksi adalah teks eksposisi yang diajarkan pada kelas 8 di KD 3.6-4.6. Kristyanawati, dkk (2019) mengemukakan bahwa teks eksposisi merupakan teks yang menginformasikan sebuah peristiwa dengan jelas guna meyakinkan pembaca mengenai sebuah informasi. Lebih lanjut, Dwinuryati, dkk (2017) mengemukakan bahwa guna meyakinkan pembaca mengenai sebuah informasi yang disampaikan di dalam teks eksposisi, maka teks eksposisi haruslah ditulis dengan utuh dan padu guna tersampaikannya pesan penulis kepada pembaca. Menurut Muliana (2018) adapun ciri dari jenis teks ini adalah pengungkapan informasi dan argumen yang disajikan dengan bahasa yang persuasif dan bersifat netral. Teks ekpsosisi umumnya memiliki struktur yakni tesis, rangkaian argumen, dan pernyataan ulang pendapat. Berdasarkan pendapat di atas, dapat disimpulkan bahwa teks eksposisi merupakan salah satu jenis teks nonfiksi yang berdasarkan fakta dan hendaknya ditulis dengan utuh dan padu supaya pesan yang hendak disampaikan penulis dapat tersampaikan kepada pembaca dengan baik.

\section{B. METODE PENELITIAN}

Penelitian ini menggunakan pendekatan kualitatif dan metode analisis deskriptif kualitatif. Hudhana (2020) mengemukakan bahwa penelitian kualitatif merupakan sebuah penelitan yang mengarah kepada metode analisis deskripstif kualitatif. Data dalam penelitian ini yaitu afiksasi dalam teks eksposisi karya siswa kelas 8 SMP Bina Mandiri Teluknaga. Sumber data primer yakni karangan teks eksposisi karya siswa kelas 8 SMP Bina Mandiri Teluknaga dan data sekunder berupa buku, jurnal penelitian, dan sumber/referensi pendukung. Teknik pengumpulan data yang digunakan adalah baca dan catat. Teknik analisis menggunakan reduksi data, penyajian data dan penarikan simpulan.

\section{HASIL TEMUAN DAN PEMBAHASAN}

Berdasarkan penelitian yang telah dilakukan, hasil penelitian yang akan disajikan dalam bab ini adalah afiksasi-afiksasi yang terdapat pada teks eksposisi karangan siswa kelas 8 SMP Bina Mandiri Teluknaga yang meliputi (1) prefiks, (2) infiks (3) sufiks, dan (4) konfiks. Pada poin ini akan dijabarkan hasil penelitian dalam bentuk hasil analisis yang disajikan dalam bentuk tabel serta dijelaskan dalam bentuk pembahasan. Pembahasan dalam penelitian ini dilakukan secara deskriptif. Berikut merupakan tabel yang berisi hasil analisis dari afiksasi teks eksposisi karangan Siswa kelas 8 SMP Bina Mandiri Teluknaga.

\section{Prefiks}




\section{Lingua Rima: Jurnal Pendidikan Bahasa dan Sastra Indonesia \\ Vol. 11 No. 1 Januari 2022 \\ http://jurnal.umt.ac.id/index.php/lgrm}

Prefiks merupakan varian afiksasi yang ciri utamanya adalah penambahan imbuhan pada awal bentuk kata dasar. Pada penelitian ini ditemukan pembubuhan prefiks berupa meN-, ber-, dan ter-. Prefiks-prefiks tersebut memiliki makna yang baru setelah mendapatkan imbuhan pada awal bentuk kata dasar.

\section{a) meN- atau meng-}

Prefiks meN- atau dapat disebut juga dengan prefiks meng- adalah varian prefiks yang digunakan untuk menerangkan kata kerja pada bentuk kata dasar yang telah mendapatkan afiksasi prefiks. Prefiks meN-atau meng- akan meluluhkan bentuk kata dasar yang berawalan huruf $\mathrm{k}, \mathrm{t}, \mathrm{s}$, dan $\mathrm{p}$, namun jika bentuk kata dasar memiliki dua atau lebih huruf konsonan di awal, maka tetap ditulis. Kata kerja merupakan sebuah kata yang menggambarkan kegiatan-kegiatan yang menggambarkan ciri "kerja" sehingga menimbulkan makna dari "kata kerja" terhadap bentuk kata dasar. Pada penelitian ini prefiks meN- atau meng- yang ditemukan adalah dengan varian-varian prefiks pembentuk kata kerja men-, mem-, meny-, meng-.

“... kita harus menjaga kebersihan supaya nyaman di sekolah ..."

Kata menjaga merupakan varian prefiks meN- (meng-) dengan komposisi kata meliputi varian prefiks men- dan bentuk kata dasar jaga sehingga membentuk kata menjaga dan memiliki makna sebagai kegiatan berupa melindungi dari segala bentuk bahaya, atau dapat pula dimaknai sebagai kegiatan berupa kegiatan mempertahankan, mengawal, mengasuh, melindungi, dan lain sebagainya. Penggunaan dan penempatan kata menjaga pada kutipan kalimat di atas yang ditulis siswa telah benar dan tepat, hal demikian berupa penegasan untuk menjaga kebersihan sekolah agar terciptanya kenyamanan di sekolah. Berdasarkan kutipan tersebut, kemampuan siswa dalam menulis bentuk kata dasar jaga yang mendapatkan prefiks meN- (meng-) berupa mensudah baik dan tepat sehingga membentuk kata yang sesuai dan bermakna.

“... mudah menyebar pada manusia ..."

Kata menyebar merupakan varian prefiks meN- dengan komposisi berupa meny dan bentuk kata dasar sebar. Bentuk kata dasar yang diawali huruf k, t, s, dan p akan luluh ketika mendapat imbuhan meN, hal tersebut membentuk kata menyebar yang memiliki makna kian meluas atau lain sebagainya. Penggunaan dan penempatan kata menyebar pada kutipan kalimat di atas yang ditulis siswa telah benar dan tepat, dalam hal ini informasi yang ditulis adalah mengenai Covid-19, kutipan di atas berupa 


\section{Lingua Rima: Jurnal Pendidikan Bahasa dan Sastra Indonesia \\ Vol. 11 No. 1 Januari 2022 \\ http://jurnal.umt.ac.id/index.php/lgrm}

informasi bahwa Covid-19 mudah menyebar pada manusia. Berdasarkan kutipan tersebut, kemampuan siswa dalam menulis bentuk kata dasar sebar yang mendapatkan prefiks meN- (meng-) berupa meny- sudah baik dan tepat sehingga membentuk kata yang sesuai dan bermakna.

“... dan mencegah dengan cara ..."

Kata mencegah terdiri atas varian men dan dan bentuk kata dasar cegah, hal demikian membentuk kata mencegah yang berarti menjaga dan berusaha untuk melindungi diri atau lain sebagainya. Penggunaan dan penempatan kata mencegah pada kutipan kalimat di atas yang ditulis siswa telah benar dan tepat, dalam hal ini informasi yang ditulis adalah mengenai Covid-19, kutipan di atas berupa informasi bahwa Covid-19 dapat dicegah dengan cara yang telah ditetapkan pemerintah. Berdasarkan kutipan tersebut, kemampuan siswa dalam menulis bentuk kata dasar yang mendapatkan prefiks meN- (meng-) berupa men- sudah baik dan tepat sehingga membentuk kata yang sesuai dan bermakna.

\section{b) ber-}

Sama halnya dengan varian prefiks meN- (meng-), varian prefiks ber- pun diimbuhkan didepan bentuk kata dasar untuk membentuk verba atau kata kerja. Prefiks ber- memiliki varian di antaranya be- dan bel-. Penggunaan prefiks ber- pada bentuk kata dasar dapat menerangkan bentuk kepemilikan, pemakakaian, menghasilkan, dan lain-lain. Pada varian ini tidak ada syarat peleburan huruf konsonan seperti varian meN- (meng-).

“... jangan lupa makan dan berdoa ..."

Pada kata berdoa pun memiliki struktur prefiks ber- dan bentuk kata dasar doa, kata berdoa sendiri memiliki makna sebagai bentuk permohonan seorang hamba kepada Tuhan Yang Maha Esa untuk hal-hal yang baik dan diutarakan dengan harapan terkabul. Penggunaan dan penempatan kata berdoa pada kutipan kalimat di atas yang ditulis siswa telah benar dan tepat, dalam hal ini informasi yang ditulis adalah mengenai kesehatan dan menjaga imunitas di masa pandemi Covid-19, kutipan di atas berupa informasi bahwa cara yang dapat dilakukan adalah dengan cara menjaga pola makan dan asupan dalam tubuh dan senantiasa berdoa kepada Tuhan Yang Maha Esa. Berdasarkan kutipan tersebut, kemampuan siswa dalam menulis 
bentuk kata dasar doa yang mendapatkan prefiks ber- varian ber- sudah baik dan tepat sehingga membentuk kata yang sesuai dan bermakna.

c) ter-

Sama halnya dengan prefiks meN- (meng-) dan ber-, prefiks ter- pun diimbuhkan didepan bentuk kata dasar untuk membentuk verba atau kata kerja. Prefiks bermemiliki varian di antaranya te- dan tel-. Penggunaan prefiks ter- pada bentuk kata dasar dapat menerangkan bentuk yang "paling" atau dapat pula menerangkan keadaan dalam kegiatan, telah dialami, dan lain-lain. Pada varian ini tidak ada syarat peleburan huruf konsonan seperti yang terdapat pada varian meN- (meng-). Hal lain yang diperhatikan ialah prefiks ter- dengan varian te- dan tel- akan memiliki makna kesanggupan untuk melakukan sebuah hal jika didahului kata tidak atau berakhiran (sufiks) -kan.

“... supaya tidak terkena penyakit.”

Pada kata terkena dibentuk berdasarkan prefiks ter- dan bentuk kata dasar kena, hal tersebut membuat kata terkena dan memiliki makna sebagai telah kena dari sebuah hal, namun berkenaan dengan kata yang mendahuluinya adalah tidak, maka hal tersebut dapat dimaknai sebagai kesangupan untuk tidak terkena sebuah hal, dalam kalimat di atas yakni penyakit. Penggunaan dan penempatan kata terkena pada kutipan kalimat di atas yang ditulis siswa telah benar dan tepat. Informasi berupa penegasan yang ditulis siswa di atas hendak menyampaikan kebersihan dan kesehatan lingkungan dalam masyarakat, hal demikian telah sesuai dengan maksud yang hendak disampaikan kepada pembaca, usaha-usaha tersebut diwujudkan untuk terciptanya kesehatan dan agar tidak terkena penyakit. Berdasarkan kutipan tersebut, kemampuan siswa dalam menulis bentuk kata dasar kena yang mendapatkan prefiks ter- varian tersudah baik dan tepat sehingga membentuk kata yang sesuai dan bermakna.

"Lingkungan kita harus terjaga ..."

Pada kata terjaga memiliki pola kalimat yakni prefiks ter- dan bentuk kata dasar jaga, hal tersebut membentuk kata terjaga yang memiliki makna terbangun (tidak tidur), terpelihara, dan dapat pula dimaknai sebagai bentuk hal dilindungi, pada kalimat di atas hal yang maksudkan adalah lingkungan yang harus terjaga. Penggunaan dan penempatan kata terjaga pada kutipan kalimat di atas yang ditulis siswa telah benar dan tepat. Informasi berupa penegasan yang ditulis siswa di atas 


\section{Lingua Rima: Jurnal Pendidikan Bahasa dan Sastra Indonesia \\ Vol. 11 No. 1 Januari 2022 \\ http://jurnal.umt.ac.id/index.php//grm}

hendak menyampaikan kebersihan lingkungan dalam masyarakat, hal demikian telah sesuai dengan maksud yang hendak disampaikan kepada pembaca, usaha-usaha tersebut diwujudkan untuk terciptanya kesehatan dan agar lingkungan di dalam masyarakat terjaga kebersihan dan kenyamanannya. Berdasarkan kutipan tersebut, kemampuan siswa dalam menulis bentuk kata dasar jaga yang mendapatkan prefiks ter- varian ter- sudah baik dan tepat sehingga membentuk kata yang sesuai dan bermakna.

\section{Sufiks}

Sebagaimana yang telah dibahas sebelumnya, dapat dipahami bahwa sufiks merupakan sisipan atau imbuhan yang diposisikan di belakang bentuk kata dasar. Sufiks pembentuk makna dapat digolongkan menjadi tiga kategori yakni sufiks pembentuk nomina, sufiks pembentuk adjektiva, dan sufiks pembentuk verba. Pada penelitian ini ditemukan varian sufiks pembentuk verba dengan varian -an dan -kan.

a) -an

Sufiks -an pembentuk verba yakni berupa turunan kata yang memiliki makna sebagai kegiatan yang terkait dengan pelaku atau tindakan yang banyak atau dapat pula dipahami sebagai pembentuk makna berupa kegiatan dengan pelaku dan tindakannya banyak (berbalasan).

“... badan menjadi kuat dan pikiran pun lancar."

Kata pikiran memiliki struktur atau pola kalimat yakni bentuk kata dasar pikir dan sufiks -an dan kemudian membentuk kata pikiran yang memiliki makna sebagai akal, ingatan, gagasa, dan hasil dari berpikir. Pada kutipan di atas dimaksudkan untuk kelancaran dan kejernihan di dalam berpikir. Penggunaan dan penempatan kata pikiran pada kutipan kalimat di atas yang ditulis siswa telah benar dan tepat. Informasi berupa penegasan yang ditulis siswa di atas hendak menyampaikan kesehatan tubuh yang dapat dilakukan dengan bangun pagi dan berolahraga. Berdasarkan kutipan tersebut, kemampuan siswa dalam menulis bentuk kata dasar pikiran yang mendapatkan sufiks -an sudah baik dan tepat sehingga membentuk kata yang sesuai dan bermakna.

"... kita harus bergotong royong menjaga lingkungan dengan baik."

Sama dengan pembahasan di atas, kata lingkungan di atas dibentuk oleh struktur bentuk kata dasar lingkung dan sufiks -an sehingga membentuk kata lingkungan yang 
memiliki makna daerah atau wilayah yang di dalamnya terdapat ekosistem dari makhluk hidup. Pada kutipan teks di atas dapat dipahami sebagai bagian daerah atau wilayah kemasyarakatan. Penggunaan dan penempatan kata lingkungan pada kutipan kalimat di atas yang ditulis siswa telah benar dan tepat. Informasi berupa penegasan yang ditulis siswa di atas hendak menyampaikan perihal lingkungan yang harus dijaga dengan cara gotong royong antaranggota masyarakat, hal demikian telah sesuai dengan maksud yang hendak disampaikan kepada pembaca. Berdasarkan kutipan tersebut, kemampuan siswa dalam menulis bentuk kata dasar lingkung yang mendapatkan sufiks -an sudah baik dan tepat sehingga membentuk kata yang sesuai dan bermakna.

\section{b) -kan}

Sufiks -kan pembentuk verba yakni berupa turunan kata yang memiliki makna sebagai kegiatan yang menjadikan, sungguh-sungguh, dan ditujukan kepada orang lain.

"... jangan pernah sepelekan bangun pagi ..."

Bentuk kata sepelekan adalah bentuk turunan kata tidak baku dari kata menyepelekan berasal dari bentuk kata dasar sepele dan mendapatkan konfiks meng...-kan yang memiliki makna sebagai bentuk tidak mengindahkan dan menganggap remeh segala hal. Dalam kutipan di atasberkenaan dengan bangun di pagi hari yang memang dapat dimanfaatkan untuk kegiatan-kegiatan yang bermanfaat untuk kesehatan. Penggunaan dan penempatan kata sepelekan pada kutipan kalimat di atas yang ditulis siswa nampaknya belum sesuai seperti yang telah dibahas di atas. Informasi yang ditulis siswa di atas hendak menyampaikan kesehatan tubuh dengan cara bangun pagi yang dapat dimanfaatkan untuk berolahraga dan membuat tubuh menjadi sehat. Berdasarkan kutipan tersebut, kemampuan siswa dalam menulis bentuk kata dasar sepele yang mendapatkan sufiks -kan sudah baik dan tepat sehingga membentuk kata yang sesuai dan bermakna.

"Lingkungan tersebut sangat penting untuk kita lestarikan ..."

Sama halnya dengan hal di atas, bentuk kata lestarikan pun bentuk turunan kata tidak baku dari kata melestarikan berasal dari bentuk kata dasar lestari dan mendapatkan konfiks meng-...-kan yang memiliki makna sebagai bentuk tindakan menjaga dan mempertahankan keseimbangan keadaan sebuah hal dengan tidak 


\section{Lingua Rima: Jurnal Pendidikan Bahasa dan Sastra Indonesia \\ Vol. 11 No. 1 Januari 2022 \\ http://jurnal.umt.ac.id/index.php/lgrm}

mengubah keadaan atau kondisi semula. Penggunaan dan penempatan kata lestarikan pada kutipan kalimat di atas yang ditulis siswa belum benar dan tepat seperti yang telah disebutkan di atas. Informasi yang ditulis siswa di atas hendak menyampaikan keadaan lingkungan yang bersih dan asri penting untuk dilestarikan keberadaannya. Berdasarkan kutipan tersebut, kemampuan siswa dalam menulis bentuk kata dasar lestari yang mendapatkan sufiks -kan sudah baik dan tepat sehingga membentuk kata yang sesuai dan bermakna.

\section{Konfiks}

Konfiks dipahami sebagai varian afiksasi yang ciri utamanya ialah kombinasi prefiks dan sufiks. Penempatan imbuhan pada awal dan akhir bentuk kata dasar dapat dibagi atas tiga jenis yakni konfiks pembentuk verba, konfiks pembentuk nomina, dan konfiks pembentuk adjektiva. Varian dari konfiks yang ditemukan pada penelitian ini adalah ke...-an, dan pe-...-an atau disebut juga dengan peng-...-an dan varian per-...-an.

\section{a) $\mathrm{Ke}-$ an}

Varian konfiks ke-...-an dapat dipahami sebagai imbuhan yang diletakkan pada awal dan akhir bentuk kata dasar. Pada varian ini terdapat tiga klasifikasi pembentuk makna yakni konfiks pembentuk verba dengan tanda berupa bentuk "dialami", konfiks pembentuk nomina ditandai dengan kata yang memiliki ciri atau sifat dan tempat, dan konfiks pembentuk adjektiva ditandai dengan ciri "terlalu".

$$
\text { “... lalu barang-barang kebasahan ..." }
$$

Pada kata kebasahan di atas, termasuk ke dalam konfiks pembentuk verba, terbentuk oleh struktur bentuk kata dasar basah dan konfiks ke-an sehingga membentuk kata kebasahan yang memiliki arti sebagai bentuk mengalami kejadian berupa basah yang menerpa tubuh atau benda/hal lainnya. Penggunaan dan penempatan kata kebasahan pada kutipan kalimat di atas yang ditulis siswa telah benar dan tepat. Informasi yang ditulis siswa di atas hendak menyampaikan bahwa kebersihan lingkungan sekolah dan rumah penting untuk dijaga dengan tidak membuang sampah sembarangan yang menyebabkan banjir, hal demikian telah sesuai dengan maksud yang hendak disampaikan kepada pembaca dengan cara menjaga kebersihan di lingkungan sekitar agar menjaga kebersihan dan tidak menyebabkan barang-barang (milik warga sekitar) kebasahan karena banjir. Berdasarkan kutipan tersebut, kemampuan siswa dalam menulis bentuk kata dasar basah yang 


\section{Lingua Rima: Jurnal Pendidikan Bahasa dan Sastra Indonesia \\ Vol. 11 No. 1 Januari 2022 \\ http://jurnal.umt.ac.id/index.php/lgrm}

mendapatkan konfiks $k e$--an sudah baik dan tepat sehingga membentuk kata yang sesuai dan bermakna.

“... mengikuti protokol kesehatan ..."

Kata kesehatan termasuk ke dalam konfiks pembentuk nomina, kata tersebut terbentuk oleh struktur bentuk kata dasar sehat dan konfiks ke-an sehingga membentuk kata kesehatan yang memiliki makna sebagai bentuk keadaan yang sehat dan berkenaan dengan kondisi tubuh (badan) atau lain hal sebagainya. Pada kutipan di atas dipahami bahwa yang dimaksudkan adalah kesehatan masa pandemi Covid-19 dan diimbau untuk selalu menerapkan protocol kesehatan agar terhindar dari Covid-19. Penggunaan dan penempatan kata kesehatan pada kutipan kalimat di atas yang ditulis siswa telah benar dan tepat. Informasi yang ditulis siswa di atas hendak menyampaikan kesehatan di masa pandemi Covid-19 dengan cara menerapkan protokol kesehatan sebagai salah satu ikhtiar. Berdasarkan kutipan tersebut, kemampuan siswa dalam menulis bentuk kata dasar sehat yang mendapatkan konfiks ke--an sudah baik dan tepat sehingga membentuk kata yang sesuai dan bermakna.

\section{b) Peng-an dan per-an}

Varian konfiks pe-...-an (peng-...-an) dapat dipahami sebagai imbuhan yang diletakkan pada awal dan akhir bentuk kata dasar. Varian konfiks dari peng-an antara lain pe — an, pem—an, pen—an, penge—an, dan peny—an. Jenis konfiks ini diklasifikasikan sebagai konfiks pembentuk nomina dengan ciri menunjukkan proses, hasil dari proses, dan tempat.

“... buku sekolah, pendidikan, buku komik, buku cerita ..."

Pendidikan memiliki struktur pembentuk yakni varian konfiks pen-an dan bentuk kata dasar didik sehingga membentuk kata pendidikan dan memiliki makna sebagai proses membentuk sikap, perilaku, dan karakter dan usaha guna mendewasakan manusia dengan pelatihan dan pengajaran. Pada kutipan di atas dimaksudkan sebagai salah satu jenis buku pendidikan dan kaitan dengan pembelajaran di sekolah. Penggunaan dan penempatan kata pendidikan pada kutipan kalimat di atas yang ditulis siswa telah benar dan tepat. Informasi yang ditulis siswa di atas hendak menyampaikan jenis-jenis buku yang dapat dibaca siswa untuk menambah informasi, wawasan, dan ilmu pengetahuan. Berdasarkan kutipan tersebut, kemampuan siswa dalam menulis bentuk kata dasar didik yang mendapatkan konfiks 


\section{Lingua Rima: Jurnal Pendidikan Bahasa dan Sastra Indonesia \\ Vol. 11 No. 1 Januari 2022 \\ http://jurnal.umt.ac.id/index.php/lgrm}

peng--an berupa pen - an sudah baik dan tepat sehingga membentuk kata yang sesuai dan bermakna.

\section{"... untuk mendapatkan ilmu pengetahuan yang luas."}

Pengetahuan memiliki struktur pembentuk yakni varian konfiks penge-an dan bentuk kata dasar tahu sehingga membentuk kata pengetahuan dan memiliki makna sebagai hasil dari pembelajaran dan transfer ilmu yang telah diketahui. Pada kutipan di atas dimaksudkan sebagai pengetahuan yang didapatkan setelah membaca buku dan mengikuti pembelajaran di sekolah. Penggunaan dan penempatan kata pengetahuan pada kutipan kalimat di atas yang ditulis siswa telah benar dan tepat. Informasi yang ditulis siswa di atas hendak menyampaikan bahwa dengan membaca dan belajar dapat menambah ilmu pengetahuan dan informasi dari buku yang dibaca dan berdampak pada luasnya ilmu pengetahuan pembaca. Berdasarkan kutipan tersebut, kemampuan siswa dalam menulis bentuk kata dasar didik yang mendapatkan konfiks peng--an berupa penge - an sudah baik dan tepat sehingga membentuk kata yang sesuai dan bermakna.

“... dalam mata pelajaran apa saja ..."

Kata pelajaran memiliki struktur pembentuk yakni konfiks per-an dengan varian pel-...-an. dan bentuk kata dasar ajar sehingga membentuk kata pelajaran dan memiliki makna yang diajarkan dan juga berupa latihan. Pada kutipan di atas dimaksudkan sebagai mata pelajaran yang diajarkan di sekolah. Penggunaan dan penempatan kata pelajaran pada kutipan kalimat di atas yang ditulis siswa telah benar dan tepat. Informasi yang ditulis siswa di atas hendak menyampaikan bahwa membaca buku yang berkaitan dengan pembelajaran dapat membuat ilmu pengetahuan pembaca bertambah luas. Berdasarkan kutipan tersebut, kemampuan siswa dalam menulis bentuk kata dasar ajar yang mendapatkan konfiks per--an berupa pel—an sudah baik dan tepat sehingga membentuk kata yang sesuai dan bermakna.

\section{SIMPULAN DAN SARAN}

Berdasarkan 16 teks eksposisi karya siswa Kelas 8 SMP Bina Mandiri Teluknaga ditemukan hasil penelitian sebanyak 58 temuan, antara lain: a) prefiks; meN- sebanyak 17 data, ber- sebanyak 13 data, dan ter- sebanyak 5 data; b) tidak ditemukan infiks; c) sufiks; -an sebanyak 9 data dan -kan sebanyak 2 data; d) konfiks: ke — an sebanyak 8 data dan peng-an sebanyak 4 data. Hasil temuan ialah berupa bentuk kata dasar yang telah mendapatkan 
afiksasi yang telah disebutkan di atas, bentuk kata yang telah mendapatkan afiksasi membentuk makna meliputi verba dan nomina. Hal-hal tersebut umumnya digunakan untuk memberikan penegasan terhadap kata yang ada di depan atau di belakangnya. Berdasarkan hasil hasil temuan dan pembahasan di atas, kemampuan siswa dalam menulis bentuk kata dasar yang mendapatkan afiksasi berupa prefiks, sufiks, dan konfiks telah baik dan tepat sehingga membentuk kata yang sesuai dan bermakna. Penelitian ini dapat memberikan saran kepada siswa dalam penggunaan afiksasi yang benar, dan kepada guru agar memperhatikan siswa dalam memberikan pembelajaran mengenai afiksasi.

\section{E. DAFTAR PUSTAKA}

Azwardi. (2015). Morfologi Bahasa Indonesia. Banda Aceh: Bina Karya Akademika.

Bunau, E. (2017). "Alomorf Nasalisasi dan Nasal Penambah dalam Bahasa Bidayuh-Somu”. Jurnal Kajian Pembelajaran dan Keilmuan 1 (2): 89-101. https://jurnal.untan.ac.id/index.php/jurnalkpk/article/view/25271/75676580041 diunduh 1 April 2021).

Busri, H \& Badrih, M. (2018). Linguistik Indonesia; Pengantar Memahami Hakikat Bahasa. Malang: Madani Media.

Chaer, A. (2015). Morfologi Bahasa Indonesia (Pendekatan Proses). Jakarta: Penerbit Rineka Cipta.

Dwinuryati, Y., dkk. (2018). "Analisis Kohesi Gramatikal dan Leksikal pada Teks Eksposisi Siswa Kelas 10 Sekolah Menengah Atas". Scholaria: Jurnal Pendidikan dan Kebudayaan 8 (1): 61-69. https://ejournal.uksw.edu/scholaria/article/view/1253/794 (diunduh 15 April 2021).

Finoza, L. (2010). Komposisi Bahasa Indonesia; Untuk Mahasisiswa Nonjurusan Bahasa. Jakarta: Diksi Insan Mulia.

Herawati, R., dkk. (2019). "Analisis Afiksasi dalam Kata-Kata Mutiara pada Caption di Media Sosial Instagram dan Implikasinya Terhadap Pembelajaran Bahasa Indonesia di SMP". Jurnal Membaca UNTIRTA 4 (1): 45-50. https://jurnal.untirta.ac.id/index.php/jurnalmembaca/article/view/6236/4379 (diunduh 18 April 2021).

Hudhana, Winda Dwi. 2020. Modul Keterampilan Menulis Ilmiah. Kota Tangerang: Pusat Bahasa Universitas Muhammadiyah Tangerang.

Jannah, M. (2020). "Afiksasi (Prefiks dan Sufiks) dalam Kolom Ekonomi Bisnis di Koran Jawa Pos Edisi Kamis 14 November 2019”. Jurnal Disastri (Jurnal Pendidikan Bahasa $\begin{array}{lllll}\text { dan } & \text { Sastra } & \text { Indonesia) } & 2 & \text { (1): }\end{array}$ http://ejournal.unhasy.ac.id/index.php/disastri/article/view/874/693 (diunduh 1 Maret 2021).

Kencanawati, N. W., dkk. (2017). "Analisis Pemakaian Afiks pada Kumpulan Puisi Malu (Aku) Jadi Orang Indonesia Karya Taufiq Ismail”. Jurnal Humanis, Fakultas Ilmu Budaya Unud 21 (1): 12-18. https://ojs.unud.ac.id/index.php/sastra/article/view/35131 (diunduh 18 April 2021).

Krisanjaya \& Yuniseffendri. (2019). Linguistik Umum (Edisi 2). Tangerang Selatan: Universitas Terbuka. 
Kusmiarti, R \& Fitriayani, R. (2019). “Afiksasi Bahasa Rejang Dialek Kepahiang”. Jurnal Lateralisasi 7 (1): 33-43. http://jurnal.umb.ac.id/index.php/lateralisasi/article/download/199/200 (diunduh 17 April 2021).

Mandia, I. N. (2019). "Penelurusan Bentuk Baku Kata Bahasa Indonesia”. SOSHUM: Jurnal $\begin{array}{lllll}\text { Sosial dan } & \text { Humaniora } & 6 & \text { (1): }\end{array}$ http://ojs.pnb.ac.id/index.php/SOSHUM/article/download/123/98 (diunduh pada 21 Februari 2021).

Mardiyah, S., dkk. (2019). "Analisis Kesalahan Morfologi dalam Karangan Narasi Berdasarkan Cerita Fantasi Irisan Pada Siswa Kelas VII SMP Negeri 1 Bandar Lampung". Warahan: Jurnal Ilmiah Mahasiswa Pendidikan Bahasa STKIP PGRI $\begin{array}{llll}\text { Bandar } \quad \text { Lampung } & 1 & \text { (2): }\end{array}$ http://eskripsi.stkippgribl.ac.id/index.php/warahan/article/view/279 $\quad$ (diunduh 17 Februari 2021).

Masita, N. S. \& Duwila, E. (2019). "Morfem (Ma-) dalam Bahasa Ternate”. Jurnal Tekstual 17 (2): 72-81. https://ejournal.unkhair.ac.id/index.php/tekstual/article/view/1795/1918 (diunduh 13 Maret 2021).

Muliana, S. (2018). Panduan Mahir Berbahasa Indonesia. Yogyakarya: Penerbit Cahaya Pendidikan.

Mulyono, I. (2013). Ilmu Bahasa Indonesia, Morfologi: Teori dan Sejumput Problematik Terapannya. Bandung: CV Yrama Widya.

Munandar, Y. (2016). "Afiks Pembentuk Verba Bahasa Sunda". Jurnal Humanika 16 (1). http://ojs.uho.ac.id/index.php/HUMANIKA/article/view/730 (diunduh 15 Februari 2021).

Nurfauziah, A. S \& Latifah. (2019). "Analisis Kemampuan Afiksasi pada Hasil Menulis Teks Ulasan Siswa SMP Kelas VIII". Parole: Jurnal Pendidikan Pendidikan Bahasa dan $\begin{array}{lllll}\text { Sastra } & \text { Indonesia } & 2 & (2): & 277-284 .\end{array}$ https://journal.ikipsiliwangi.ac.id/index.php/parole/article/download/2733/pdf_1 (diunduh 5 Maret 2021).

Nuryadi. (2019). "Kata dan Proses Pembentukan Kata dalam Bahasa Inggris dan Bahasa Indonesia: Suatu Analisis Kontrastif". Jurnal Makna: Jurnal Kajian Komunikasi, Bahasa, dan $\quad$ Budaya $4 \quad$ (1): http://jurnal.unismabekasi.ac.id/index.php/makna/article/view/1675 (diunduh 13 Maret 2021).

Pohan, J. E. (2019). Morfologi Bahasa Indonesia. Yogyakarta: Penerbit Deepublish.

Ramlan, M. (2001). Ilmu Bahasa Indonesia, Morfologi: Suatu Tinjauan Deskriptif. Yogyakarta: CV Karyono.

Rumilah, S \& Cahyani, I. (2020). "Struktur Bahasa; Pembentukan Kata dan Morfem Sebagai Proses Morfemis dan Morfofonemik dalam Bahasa Indonesia". Jurnal Pendidikan $\begin{array}{lllll}\text { Bahasa } & \text { Indonesia } & 8 & (1): & 70-87 .\end{array}$ http://jurnal.unissula.ac.id/index.php/jpbsi/article/view/11175 (diunduh 7 April 2021).

Sihabuddin. (2019). Terampil Berbicara dan Menulis. Yogyakarta: Araska.

Verhaar, J.W.M. 2012. Asas-asas Linguistik Umum. Yogyakarta: Gajah Mada University Press. 